\title{
GYVENSENOS VEIKSNIŲ SĄSAJOS SU GLIUKOZĖS KIEKIU KAPILIARINIAME KRAUJYJE
}

\author{
Jolita Kirvaitiené $\dot{1}^{1,2}$, Rasa Volskiené $\dot{1}^{1}$, Lina Ambrožiené $\dot{1}^{1}$, Albina Vaičiulevičienė ${ }^{1}$ \\ ${ }^{1}$ Kauno kolegijos Medicinos fakultetas, \\ ${ }^{2}$ Lietuvos sveikatos mokslu universiteto Medicinos akademija
}

\author{
Raktažodžiai: cukrinis diabetas, gyvensena, kapiliarinis \\ kraujas.
}

\begin{abstract}
Santrauka
Tarptautinès diabeto federacijos duomenimis, pasaulyje diabetu serga $415 \mathrm{mln}$. žmonių, iš kurių apie 90 proc. sudaro sergantys II tipo cukriniu diabetu, dažniausiai siejamu su gyvensenos ịpročiais. Lietuvos statistikos departamento duomenimis, $2016 \mathrm{~m}$. Lietuvoje užregistruoti 104478 cukrinio diabeto atvejai, iš kurių - 99197 II tipo cukrinio diabeto. Gliukozès kiekis kapiliariniame kraujyje yra pagrindinis diagnostinis parametras, leidžiantis diagnozuoti diabetą ar priešdiabetinę ligos stadiją. Moksliniais tyrimais įrodyta, kad II tipo cukrinio diabeto galima išvengti laikantis darbo ir poilsio režimo, neignoruojant sveikos mitybos principų, skiriant laiko fiziniam aktyvumui. Tyrimo tikslas - nustatyti Kauno kolegijos bendruomenès narių gyvensenos ịpročių sąsajas su gliukozės kiekiu kapiliariniame kraujyje. Duomenys tyrimui rinkti 2016 m. Kauno kolegijoje vykusių 3 renginių metu: renginio, skirto paminèti tarptautinei "Sveikatos dienai" - balandžio mèn. 7 d.; renginio „Sveiki, aktyvūs, žvalūs“, vykusio spalio mèn. 2 d.; renginio, skirto tarptautinei „Cukrinio diabeto“ dienai paminèti lapkričio mèn. $14 \mathrm{~d}$. Renginių metu buvo matuojama gliukozès koncentracija kapiliariniame kraujyje, dalyviai atsakinejjo ị anketos klausimus, apibūdinančius jų gyvenseną. Tyrime dalyvavo 117 savanoriškai sutikusių tirtis Kauno kolegijos bendruomenès narių.

Tyrimo rezultatai - Kauno kolegijos bendruomenès narių gliukozès kiekio kapiliariniame kraujyje padidejimas momentinio tyrimo metu susijęs su amžiumi, kūno masès indeksu bei fiziniu aktyvumu $(p<0,05)$. Respondentai, kuriems buvo nustatytas padidejęs gliukozès kiekis kapiliariniame kraujyje, blogiau
\end{abstract}

vertino savo sveikatą bei mitybą, jų veiklą lydejo nervinè įtampa, jie dažniau rūkè.

\section{Ivadas}

Moksliniais tyrimais įrodyta, kad gyvensena yra tiesiogiai susijusi su cukrinio diabeto etiologija ir patogeneze. Vienas pagrindinių vaidmenų II tipo cukrinio diabeto vystymuisi ir progresijai tenka mitybos įtpročiams: dietos, paremtos negatyviu energijos balansu, Viduržemio jūros regiono mitybos modelis, bendras antioksidantų kiekis, valgymo ịpročiai, angliavandenių kiekis ir jų tipas, skaidulos yra labai svarbūs, kalbant apie mitybą, kontroliuojančią ir palaikančią normalų gliukozès kieki kraujyje [1]. Pasak R. A. Mekary ir kt., cukrinio diabeto vystymąsi gali sąlygoti ne tik valgomas maistas, bet ir valgymo ịpročiai. Moterys, kurios nereguliariai valgé pusryčius, turèjo didesnę tikimybę susirgti antro tipo cukriniu diabetu. Analizuojant vyrų valgymo ypatumus, nustatyta, kad užkandžiavimas tarp pagrindinių valgymų turèjo didesnę tikimybę susirgti antro tipo cukriniu diabetu [2].

Ir nors dažnas valgymas mažomis porcijomis yra paplitęs kaip viena pagrindinių mitybos rekomendacijų, sergant cukriniu diabetu [3], tačiau kai kurie tyrejai teigia, kad šis valgymo būdas tik padidina apetitą ir turi neigiamą įtaką svorio metimui [4]. Pasak R. Taylor ir Y. Saisho, individai, kurių ląstelès yra atsparios insulinui ir dèl to padidèjęs bendras insulino kiekis kraujyje, linkę kaupti riebalus kepenyse. Kaupiantis vis daugiau riebalų kepenyse hepatocitams taip pat vystosi atsparumas insulinui. Taigi, kepenys nustoja reaguoti ị insuliną, ir ị kraują nuolat išskiria gliukozę, o ị ją reaguodama kasa išskiria dar daugiau insulino. Taip palaikydama normalų gliukozès kiekị kraujyje, kol galiausiai riebalai patenka ị kasos ląsteles, kur sukelia beta ląsteliu disfunkciją, kasa nebepajegia išskirti užtektinai insulino ir gliukozès kiekis kraujyje pradeda didèti. Šio proceso pasekmės matomos tik tuomet, kai organai jau būna pažeisti, nors šis lètas patologinis procesas būna prasidèjęs ir prieš dešimtmetị [5]. 
T. Wirstrom ir A. Hilding teigia, kad viso grūdo maisto produktai mažina gliukozès kiekio šuolius kraujyje, didesnis skaidulų kiekis padeda kontroliuoti bei valdyti metabolinius procesus $[6,7]$. Tuo tarpu su maistu gaunamos riebiosios rūgštys, patekusios ị kraują lipidų infuzijos būdu, pažeidžia insuliną gaminančių ląstelių veiklą. Mažo tankio cholesterolis tarpininkauja šių ląstelių lipotoksiniai žǔčiai reikalingiems procesams. Šių medžiagų gausu riebiuose gyvulinès kilmès produktuose. Pan A., Sun Q. ir kt. Jungtinėse Amerikos Valstijose atlikto tyrimo duomenimis, perdirbti ir neperdirbti raudonos mèsos gaminiai didina riziką susirgti antro tipo diabetu. Nustatyta, kad per dieną 100 gramų neperdirbtos mésos arba 50 gramų perdirbtos pakeitus ị porciją riešutų ar mažai riebalų turinčius pieno ar viso grūdo produktus, rizika susirgti antro tipo diabetu sumažeja 16 - 36 proc. [8]. Zoncu R., Sabatini D.M. ir kt. teigia, kad pieno produktai (kaip ir mėsos) turi daug amino rūgšties - leucino, kuris pažeidžia kasos $\beta$-ląsteles. Taigi, geresnius rezultatus gausime pakeitę pieno ir mésos produktus ị augalinès kilmès baltymus [9]. Gausus kiaušinių vartojimas yra tiesiogiai siejamas su padidejusia antro tipo diabeto rizika, ypač moterims [10]. Monosotieji augaliniai riebalai sveikiems respondentams turi teigiamą efektą gliukozès kiekio ir insulino išskyrimo lygiams. Valgant daug perdirbtų angliavandenių turintị maistą kartu su riešutų sviestu, gliukozès ir insulino kiekiai po valgio yra žemesni, nei valgant vien perdirbtus, daug angliavandenių turinčius produktus. Respondentų, kurie su aukštą glikeminį indeksą turinčiu maistu kartu valgè ir skiltelę avokado, insulino ir gliukozès kiekiai buvo stabilesni ir žemesni, nei valgančių vien aukšto glikeminio indekso maistą [11]. Polisotieji riebalai tokio efekto neturejjo. Daug polisočiųjų riebiujų rūgščių turintys produktai, valgomi kartu su aukšto glikeminio indekso produktais, gliukozès ir insulino kiekị kraujyje didina labiau nei valgant vien tuos pačius produktus be pridètinio riebalų šaltinio [12]. Riebios žuvies ir jos produktų vartojimas Azijos šalių gyventojams mažina riziką susirgti II tipo cukriniu diabetu, o Europos šalių gyventojams - didina [13,14]. Žmonès, suvartojantys daugiau nei 3 porcijas ankštinių augalų per savaitę, beveik 4 kartus rečiau suserga cukriniu diabetu, nei visai nevartojantys ankštinių produktų žmonès $[15,16]$. Net ir nutukusiems žmonėms, padidinus ankštinių augalų suvartojimą, jau po kelių savaičiu pastebimas priešuždegiminių žymenų (CRB, C3) sumažèjimas bei žymus metabolinių funkcijų pagerèjimas $[17,18]$. Šis efektas siejamas su dideliu maistinių skaidulų kiekiu, esančiu ankštiniuose augaluose, bei fitatų, kurie lètina krakmolo skaidymą ir mažina gliukozès kiekị po valgio, kiekiu [19]. Vaisiai ir daržovès yra daugiausia antioksidantų turintis maistas [20]. Asmenys, suvartojantys daugiau antioksidantų turinčio maisto, turèjo mažesnị kūno masès indeksą, mažesnị riebalų kiekị juosmens srityje, jie rečiau sirgo II tipo cukriniu diabetu [21], o asmenims, jau turintiems gliukozės reguliacijos sutrikimų, dieta, praturtinta antioksidantais, padejjo sumažinti kūno masès indeksą, juosmens apimtį, trigliceridų kiekị bei gliukozès koncentraciją nevalgius [22]. Didelis perdirbto cukraus vartojimas yra siejamas su padidèjusia diabeto rizika. Daug perdirbto cukraus turintys gėrimai sukelia dideli gliukozės šuolį kraujyje, kasa, reaguodama į stiprų dirginimą, išskiria per daug insulino, kuris per daug sumažina cukraus kiekị kraujyje. [23]. Vartojant natūralius monosacharidų turinčius produktus kartu su perdirbtais, insulino šuoliai nebuvo tokie ryškūs, nors bendras cukraus kiekis buvo suvartotas daug didesnis [24]. Nustatyta, kad vartojant standartinị mègini ( $35 \mathrm{~g}$ cukraus) gliukozès ir insulino kiekis kraujyje padideja labiau, nei vartojant tą pati mėginị kartu su tam tikromis uogomis, nors bendras cukraus kiekis yra didesnis [25]. Švedijoje atlikto tyrimo duomenys patvirtina, kad maži retai vartojamo alkoholio kiekiai mažina riziką susirgti antro tipo cukriniu diabetu, tačiau vartojantiems alkoholį nuolat, gliukozès reguliacijos mechanizmas sutrinka [26].

Stresas taip pat didina gliukozės kiekị kraujyje. 2016 metais buvo nustatyta sąsaja tarp streso valdymo įvertinimų ir II tipo cukrinio diabeto rizikos padidejimo. Respodentai, ịvertinę savo streso valdymą prastai, turejo iki 50 proc. didesnę tikimybę susirgti antro tipo cukriniu diabetu nei respondentai, įvertinę ši gebejimą gerai ar labai gerai. Moterims, patiriančioms vidutinio/aukšto lygio stresą, tikimybe susirgti II tipo cukriniu diabetu padideja 2,3 karto [33,34].

Nikotinas skatina streso hormonu (kortizolio, epinefrino ir norepinefrino) išsiskyrimą. Rūkymas siejamas su didesniu riebalų kaupimusi pilvo srityje [27]. Surūkantys mažiau nei 10 cigarečių per dieną arba ne mažiau kaip 20 pokelių per metus, turi 19 proc. didesnę riziką susirgti II tipo cukriniu diabetu. Surūkantys 10-20 cigarečių per dieną arba 20 - 40 pakeliu per metus -34 proc didesnę riziką susirgti II tipo cukriniu diabetu, o surūkantys per 20 cigarečių per dieną arba per 40 pakeliu per metus -60 proc. didesnę riziką susirgti II tipo cukriniu diabetu [28]. Nustatyta, kad sumažeję̨s plaučių funkcionalumus, kurị dažnai sukelia rūkymas, sutrikdo gliukozès pasisavinimą bei padidina riziką susirgti antro tipo cukriniu diabetu [29].

Pasak J.J. Dubbe ir kt., fizinis aktyvumas yra vienas svarbiausių diabeto prevencinių faktorių. Fizinis aktyvumas skatina kraujo pritekèjimą ị raumenis, didina ląstelès jautrumą insulinui, padeda palaikyti normalų kūno svorị. Po treniruotès gliukozès pasisavinimo greitis padideja keliasdešimčia procentų [30]. Vidutinis fizininis aktyvumas ir raumenų stiprinimas (joga, pasipriešinimo treniruotès ir kt.) yra sietinas su esminiu diabeto rizikos sumažèjimu $[31,32]$. 


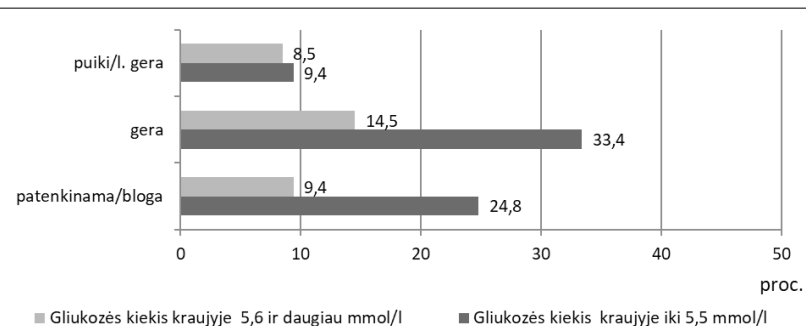

1 paveikslas. Respondentų subjektyvus sveikatos vertinimo dažnis (proc.), atsižvelgiant ị gliukozès kiekị kapiliariniame kraujyje tyrimo metu

1 lentelè. Respondentams tyrimo metu nustatyto gliukozès kiekio kapiliariniame kraujyje pasiskirstymas (proc.), atsižvelgiant į amžių, lytị bei kūno masès indeksą

\begin{tabular}{|c|c|c|c|c|}
\hline \multirow{2}{*}{\multicolumn{2}{|c|}{ Veiksniai }} & \multicolumn{2}{|c|}{$\begin{array}{c}\text { Gliukozès kiekis kraujyje } \\
\text { tyrimo metu } \\
\mathrm{N}=117\end{array}$} & \multirow{2}{*}{$\begin{array}{l}\text { Reikšmin- } \\
\text { gumas }\end{array}$} \\
\hline & & iki 5,5 & 5,6 ir dau- & \\
\hline \multirow{3}{*}{$\begin{array}{l}\text { A m ži a u s } \\
\text { grupès }\end{array}$} & $17-24 \mathrm{~m}$. & 38,5 & 12,0 & \multirow{3}{*}{$\begin{array}{c}\chi^{2}=8,438 \\
l l s=2 \\
p=0,015\end{array}$} \\
\hline & $25-50 \mathrm{~m}$ & 19,6 & 8,5 & \\
\hline & $\begin{array}{l}51 \text { ir dau- } \\
\text { giau }\end{array}$ & 9,4 & 12,0 & \\
\hline & & & & \multirow{3}{*}{$\mathrm{p}>0,05$} \\
\hline \multirow{2}{*}{ Lytis } & Vyrai & 15,4 & 7,7 & \\
\hline & Moterys & 52,1 & 24,8 & \\
\hline & & & & \\
\hline \multirow{4}{*}{$\begin{array}{l}\text { Kūno masès } \\
\text { indeksas }\end{array}$} & Iki 18,5 & 2,6 & 0,9 & \multirow{4}{*}{$\begin{array}{c}\chi^{2}=14,496 \\
l l s=3 \\
p=0,002\end{array}$} \\
\hline & $18,5-25$ & 48,7 & 14,5 & \\
\hline & $25-29,9$ & 14,5 & 10,3 & \\
\hline & $\begin{array}{l}\text { daugiau } \\
\text { nei } 30\end{array}$ & 1,7 & 6,8 & \\
\hline
\end{tabular}

Darbo tikslas - nustatyti Kauno kolegijos bendruomenès narių gyvensenos ịpročių sąsajas su gliukozės kiekiu kapiliariniame kraujyje.

\section{Tyrimo medžiaga ir metodai}

Siekiant nustatyti Kauno kolegijos bendruomenès narių gyvensenos įpročių sąsajas su gliukozės kiekiu jų kapiliariniame kraujyje, duomenys tyrimui rinkti $2016 \mathrm{~m}$. Kauno kolegijoje vykusių 3 renginių metu: renginio, skirto paminèti tarptautinei "Sveikatos dienai" - balandžio mèn. 7 d.; renginio „Sveiki, aktyvūs, žvalūs“, vykusio spalio mèn. 2 d.; renginio, skirto tarptautinei „Cukrinio diabeto“ dienai paminèti lapkričio mèn. $14 \mathrm{~d}$. Tiriamujų buvo prašoma atvykti tyrimui nepusryčiavus. Tiriamają grupę sudare Kauno kolegijos bendruomenès nariai, savanoriškai sutikę išsitirti

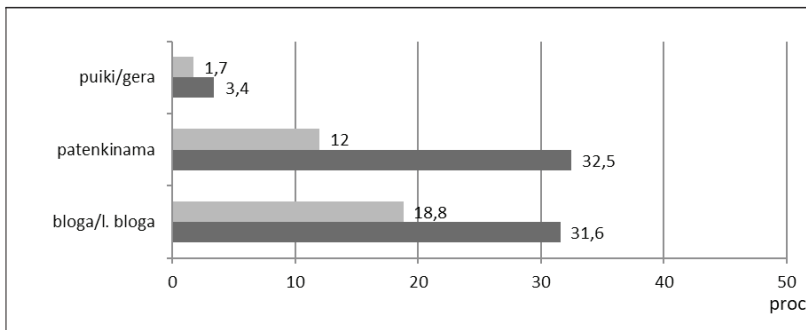

Gliukozès kiekis kraujyje 5,6 ir daugiau mmol/l Gliukozẻs kiekis kraujyje iki 5,5 mmol/l

2 paveikslas. Respondentų subjektyvus mitybos vertinimo dažnis (proc.), atsižvelgiant ị gliukozės kiekị kapiliariniame kraujyje tyrimo metu

2 lentelè. Respondentams tyrimo metu nustatyto gliukozès kiekio kapiliariniame kraujyje pasiskirstymas (proc.), atsižvelgiant ị mitybos ịpročius

\begin{tabular}{|c|c|c|c|}
\hline \multirow{2}{*}{\multicolumn{2}{|c|}{ Veiksniai }} & \multicolumn{2}{|c|}{$\begin{array}{c}\text { Gliukozès kiekis krau- } \\
\text { jyje tyrimo metu } \\
\mathrm{N}=117\end{array}$} \\
\hline & & \multirow{2}{*}{$\begin{array}{c}\begin{array}{c}\text { iki 5,5 } \\
\text { mmol/l } \\
\text { proc. }\end{array} \\
5,2\end{array}$} & \multirow{2}{*}{$\begin{array}{c}\begin{array}{c}5,6 \text { ir dau- } \\
\text { giau } \mathbf{~ m m o l} / \mathbf{l} \\
\text { proc. }\end{array} \\
1,7 \\
\end{array}$} \\
\hline \multirow{3}{*}{$\begin{array}{l}\text { Mitybos režimo } \\
\text { laikymasis }\end{array}$} & visada & & \\
\hline & \begin{tabular}{|l} 
kartais \\
\end{tabular} & 47,9 & 23,9 \\
\hline & niekada & 14,5 & 6,8 \\
\hline \multirow{2}{*}{$\begin{array}{l}\text { Valgymo kartai per } \\
\text { dieną }\end{array}$} & \begin{tabular}{|l|}
$1-3$ \\
\end{tabular} & 34,2 & 16,2 \\
\hline & 4 ir daugiau & 33,3 & 16,3 \\
\hline \multirow{3}{*}{ Pusryčiavimas } & visada & 35.0 & 18.8 \\
\hline & kartais & 29,1 & 9,4 \\
\hline & niekada & 3,4 & 4,3 \\
\hline \multirow{4}{*}{ Užkandžiavimas } & & & \\
\hline & visada & 18,8 & 12,0 \\
\hline & kartais & 40,2 & 17,1 \\
\hline & niekada & 8,5 & 3,4 \\
\hline \multirow{2}{*}{$\begin{array}{l}\text { Suvartojamas } \\
\text { daržovių kiekis per } \\
\text { dieną }\end{array}$} & < nei 400 g/d. & 42,7 & 18,8 \\
\hline & $\begin{array}{l}400 \mathrm{~g} \text { ir dau- } \\
\text { giau }\end{array}$ & 24,8 & 13,7 \\
\hline
\end{tabular}

gliukozės kiekị kapiliariniame kraujyje bei atsakyti ị gyvensenos anketos klausimus. Anketoje pateikti uždaro ir atviro tipo klausimai, grupuojant juos ị dalis: bendra informacija (amžius, lytis, ūgis, svoris); elgsena, susijusi su mityba, fiziniu aktyvumu, darbo poilsio režimu. Anketos peržiūrètos, atrinkta 117 pilnai užpildytų anketų. Atlikta statistiné duomenų analizė, naudojant statistinị programų paketą SPSS 20.0, apskaičiuojant procentinius duomenų ịverčius. Kintamujų (tiriamụjų požymių) kaupimui buvo naudojamas 
programų paketas Microsoft Office MSExcel. Kokybinių požymių statistinis ryšys tirtas taikant chi kvadrato $\left(\chi^{2}\right)$ kriterijų. Statistinių hipotezių reikšmingumui įvertinti pasirinktas reikšmingumo lygmuo $\mathrm{p}<0,05$.

\section{Rezultatai}

Atlikus Kauno kolegijos bendruomenès narių momentinio kraujo tyrimo, kurio metu buvo matuojamas gliukozès kiekis kapiliariniame kraujyje, duomenų analizę, nustatyta, kad trečdalis $(32,5$ proc.) respondentų turèjo padidejusi gliukozès kiekị kapiliariniame kraujyje. Išanalizavus anketinès apklausos duomenis nustatyta, kad respondentai, kuriems buvo padidèjęs gliukozès kiekis kapiliariniame kraujyje, blogiau vertino savo sveikatą. Kaip labai gerą ir gerą savo sveikatą vertino 42,8 proc. respondentų, kurių gliukozès kiekis kapiliariniame kraujyje tyrimo metu buvo iki $5,5 \mathrm{mmol} / \mathrm{l}$, ir 23 proc. respondentų, kurių gliukozės kiekis kraujyje tyrimo metu buvo 5,6 ir daugiau mmol/l (1 pav.). Taip pat nustatyta, kad blogiau savo mitybą vertino tyrimo dalyviai, kuriems buvo nustatytas padidejęs gliukozès kiekis kapiliariniame kraujyje. Kaip labai gerą ir gerą savo mitybą ịvertino 35,9 proc. respondentų, kuriu gliukozès kiekis kraujyje tyrimo metu buvo iki 5,5 mmol/l, ir 13,7 proc. respondentu, kurių gliukozės kiekis kraujyje tyrimo metu buvo 5,6 ir daugiau $\mathrm{mmol} / \mathrm{l}$ (2 pav.).

Respondentams tyrimo metu nustatyto gliukozès kiekio kapiliariniame kraujyje pasiskirstymas (proc.), atsižvelgiant i amžių, lytị bei kūno masès indeksą, pateiktas 1 lentelëje. Tyrimo metu didesnis (5,6 ir daugiau mmol/l) gliukozès kie-

3 lentelè. Respondentams tyrimo metu nustatyto gliukozès kiekio kapiliariniame kraujyje pasiskirstymas (proc.), atsižvelgiant ị gyvensenos veiksnius

\begin{tabular}{|c|c|c|c|c|}
\hline \multirow{2}{*}{\multicolumn{2}{|c|}{ Veiksniai }} & \multicolumn{2}{|c|}{$\begin{array}{c}\text { Gliukozès kiekis } \\
\text { (mmol/) kraujyje } \\
\text { tyrimo metu } \\
\mathrm{N}=117\end{array}$} & \multirow{2}{*}{$\begin{array}{l}\text { Reikšmin- } \\
\text { gumas }\end{array}$} \\
\hline & & $\begin{array}{l}\text { iki } 5,5 \\
\text { proc. }\end{array}$ & $\begin{array}{c}5,6 \text { ir } \\
\text { daugiau } \\
\text { proc. }\end{array}$ & \\
\hline \multirow{2}{*}{$\begin{array}{l}\text { Fizinis akty- } \\
\text { vumas }\end{array}$} & $\begin{array}{l}\text { Sportuoja regu- } \\
\text { liariai }\end{array}$ & 38,5 & 6,0 & \multirow{2}{*}{$\begin{array}{c}\chi^{2}=15,436 \\
\text { lls }=1 \\
p=0,0001\end{array}$} \\
\hline & nesportuja & 29,1 & 26,5 & \\
\hline \multirow{3}{*}{ Rūkymas } & & & & \multirow{3}{*}{$\mathrm{p}>0,05$} \\
\hline & Rūko & 21,4 & 12,0 & \\
\hline & Nerūko & 46,2 & 20,5 & \\
\hline \multirow{2}{*}{$\begin{array}{l}\text { Veikla ly- } \\
\text { dima nervi- } \\
\text { nės įtampos }\end{array}$} & Taip & 16,2 & 10,3 & \multirow{2}{*}{$\mathrm{p}>0,05$} \\
\hline & $\mathrm{Ne}$ & 51,3 & 22,2 & \\
\hline
\end{tabular}

kis kapiliariniame kraujyje dažniau buvo nustatytas vyresnio amžiaus $(>51 \mathrm{~m}$.) žmonių grupejje nei jaunesnių žmonių grupejje $(p<0,05)$. Tolygus gliukozès kiekio kraujyje padidèjimo atvejų skaičius nustatytas jaunų (17-24 m.) bei vidutinio (25$50 \mathrm{~m}$.) amžiaus Kauno kolegijos bendruomenès narių grupėse. Analizuojant duomenis pagal lytị, statistiškai reikšmingų skirtumų nebuvo nustatyta. Tyrimo metu responentams, turintiems nepakankamą $(<18,5)$ bei normalų $(18,5-25)$ kūno masès indeksus, statistiškai reikšmingai dažniau buvo nustatytas iki 5,5 mmol/l gliukozès kiekis kapiliariniame kraujyje, skirtingai nei tiems, kurių kūno masès indeksas buvo didesnis $(25-29,9)$ bei $(>30)$.

Respondentams tyrimo metu nustatyto gliukozès kiekio kapiliariniame kraujyje pasiskirstymas (proc.), atsižvelgiant i mitybos ịpročius, pateiktas 2 lentelèje. Respondentams, kurie laikèsi mitybos režimo, gliukozès padidèjimo atvejų pasitaikè rečiau nei tiems, kurie mitybos režimo nesilaikè. Analizuojant Kauno kolegijos bendruomenès narių anketinès apklausos apie mitybos ịpročius bei momentinio kraujo tyrimo, kurio metu buvo matuojamas gliukozès kiekis kapiliariniame kraujyje, duomenis, stebimos tendencijos tarp valgymo kartų per dieną ir užkandžiavimų bei nustatyto padidejusio gliukozès kiekio kraujyje, nors statistiškai reikšmingų skirtumų nebuvo nustatyta. Tyrimo metu respondentams, suvalgantiems daugiau kaip $400 \mathrm{~g}$. daržovių per dieną, dažniau buvo nustatytas iki $5,5 \mathrm{mmol} / 1$ gliukozės kiekis kapiliariniame kraujyje.

Respondentams tyrimo metu nustatyto gliukozès kiekio kapiliariniame kraujyje pasiskirstymas (proc.), atsižvelgiant i gyvensenos veiksnius, pateiktas 3 lentelèje. Reguliariai sportuojantys bei fiziškai aktyvūs Kauno kolegijos bendruomenès nariai turèjo sąlygiškai žemą gliukozès padidèjimo procentą, skirtingai nei neaktyvūs (atitinkamai 6,0 proc. ir 26,5 proc., $\mathrm{p}<0,05)$. Rūkantiems respondentams dažniau buvo nustatytas 5,6 ir daugiau mmol/1 gliukozès kiekis kapiliariniame kraujyje. Tiriamiesiems, kurių veikla buvo lydima ịtampos, dažniau nustatyta padidejjusi gliukozès koncentracija kapiliariniame kraujyje, nei tiems, kurių veikla nebuvo lydima itampos (atitinkamai 22,2 proc. ir 10,3 proc., $\mathrm{p}<0,05$ ).

\section{Išvados}

1. Kauno kolegijos bendruomenès nariams gliukozès koncentracijos kapiliariniame kraujyje padidejjimas momentinio tyrimo metu yra susijęs su jų amžiumi, kūno masės indeksu bei fiziniu aktyvumu $(\mathrm{p}<0,05)$.

2. Kauno kolegijos bendruomenès nariai, kuriems buvo nustatyta padidejusi gliukozès koncentracija kapiliariniame kraujyje, blogiau vertino savo sveikatą bei mitybą, jų veiklą lydèjo nervinè įtampa, jie dažniau rūkè, nors statistiškai reikšmingų skirtumų nebuvo nustatyta. 


\section{Literatūra}

1. De la Iglesia R, Loria-Kohen V, Zulet MA, Martinez JA, Reglero G, \& Ramirez de Molina, A. Dietary strategies implicated in the prevention and treatment of metabolic syndrome. International Journal of Molecular Sciences 2016 Nov 10;17(11).

2. Mekary R A, Giovannucci E, Willett W C, van Dam R M, Hu F B. Eating patterns and type 2 diabetes risk in men: breakfast omission, eating frequency, and snacking. The American Journal of Clinical Nutrition 2012 May;95(5):1182-9.

3. Schwarz NA, Rigby B R, La Bounty P, Shelmadine B, Bowden, RG. A review of weight control strategies and their effects on the regulation of hormonal balance. Journal of Nutrition and Metabolism 2011;2011:237932.

4. Ohkawara K, Cornier M, Kohrt W M, Melanson E L. Effects of increased meal frequency on fat oxidation and perceived hunger. Obesity (Silver Spring) 2013 Feb;21(2):336-43.

5. Taylor R. Banting Memorial Lecture 2012 Reversing the twin cycles of type 2 diabetes Diabetic Medicine 2013 Mar;30(3):267-75.

6. Lee C, Liese A, Wagenknecht L, Lorenzo C, Haffner S, Hanley A. Fish consumption, insulin sensitivity and beta-cell function in the insulin resistance atherosclerosis study (IRAS). Nutrition, Metabolism, and Cardiovascular Diseases 2013 Sep;23(9):82935 .

7. Wirstrom T. et al. Consumption of whole grain reduces risk of deteriorating glucose tolerance, including progression to prediabetes. American Journal of Clinical Nutrition 2013 Jan;97(1):179-87.

8. Pan A, Sun Q, Bernstein A M, Schulze M B, Manson J E, Willett $\mathrm{W} \mathrm{C}, \mathrm{Hu} F \mathrm{~B}$. Red meat consumption and risk of type 2 diabetes: 3 cohorts of US adults and an updated meta-analysis. The American Journal of Clinical Nutrition 2011 Oct;94(4):108896.

9. Zoncu R, Sabatini DM, Efeyan A. mTOR: from growth signal integration to cancer, diabetes and ageing. Nature Reviews Molecular Cell Biology 2011 Jan;12(1):21-35.

10. Shi Z, Yuan B. et al. Egg consumption and the risk of diabetes in adults, Jiangsu, China. Nutrition 2011 Feb;27(2):194-8.

11. Wien M, Haddad E, Oda K, Sabaté J A randomized $3 \times 3$ crossover study to evaluate the effect of Hass avocado intake on post-ingestive satiety, glucose and insulin levels, and subsequent energy intake in overweight adults. Nutrition Journal 2013 Nov 27;12:155.

12. Sun L, Ranawana D V, Leow M K, Henry C J. Effect of chicken, fat and vegetable on glycaemia and insulinaemia to a white rice-based meal in healthy adults. European Journal of Nutrition 2014 Dec;53(8):1719-26.

13. Zhang M, Picard-Deland E, Marette A. Fish and marine omega-3 polyunsatured fatty acid consumption and incidence of type 2 diabetes: a systematic review and meta-analysis. International Journal of Endocrinology 2013;2013:501015.

14. Lee C, Liese A, Wagenknecht L, Lorenzo C, Haffner S, Hanley A. Fish consumption, insulin sensitivity and beta-cell function in the Insulin Resistance Atherosclerosis Study (IRAS). Nutrition, Metabolism, and Cardiovascular Diseases 2013 Sep;23(9):829-35.

15. Bahadoran Z, Golzarand M, Mirmiran P, Shiva N \& Azizi F. Dietary total antioxidant capacity and the occurrence of metabolic syndrome and its components after a 3-year follow-up in adults: Tehran lipid and glucose study. Nutrition \& Metabolism 2012 Jul 31;9(1):70.

16. Reverri E J, Randolp J M, Steinberg F M, Kappagoda C T, Edirisinghe I, Burton-Freeman B M. Black beans, fiber, and antioxidant capacity pilot study: examination of whole foods vs. Functional components on postprandial metabolic, oxidative stress, and inflammation in adults with metabolic syndrome. Nutrients 2015 Jul 27;7(8):6139-54.

17. Hermsdorff HH, Zulet MÁ, Martínez JA. The implication of unknown bioactive compounds and cooking techniques in relations between the variety in fruit and vegetable intake and inflammation. American Journal of Clinical Nutrition 2011 Jun;93(6):1384.

18. Alizadeh M, Gharaaghaji R \& Gargari B P. The effects of legumes on metabolic features, insulin resistance and hepatic function tests in women with central obesity: a randomized controlled trial. International Journal of Preventive Medicine 2014: 5(6), 710-720.

19. Rebello CJ, Greenway FL, Finley JW. Whole grains and pulses: acomparison of the nutritional and health benefits. Journal Agricultural and Food Chemistry 2014 Jul 23;62(29):7029-49.

20. Carlsen M H, Halvorsen B L, Holte K. The total antioxidant content of more than 3100 foods, beverages, spices, herbs and supplements used worldwide. Nutrition Journal 2010 Jan 22;9:3.

21. Bahadoran Z, Golzarand M, Mirmiran P, Shiva N, Azizi F. Dietary total antioxidant capacity and the occurrence of metabolic syndrome and its components after a 3-year follow-up in adults: Tehran Lipid and Glucose Study. Nutrition \& Metabolism 2012 Jul 31;9(1):70.

22. De la Iglesia R, Lopez-Legarrea P, Celada P, Sanchez-Muniz F J, Martinez J A, Zulet M. A. Beneficial effects of the RESMENA dietary pattern on oxidative stress in patients suffering from metabolic syndrome with hyperglycemia are associated to dietary TAC and fruit consumption. International Journal of Molecular Sciences 2013: 14(4), 6903-6919.

23. Johnson RJ, Nakagawa T, Sanchez-Lozada LG. et al. Sugar, uric acid, and the etiology of diabetes and obesity. Diabetes 2013 Oct;62(10):3307-15.

24. Törrönen R, Kolehmainen M, Sarkkinen E, Mykkänen H, Niskanen L. Postprandial glucose, insulin, and free fatty acid responses to sucrose consumed with blackcurrants and lingonberries in healthy women. The American Journal of Clinical Nutrition 2012 Sep;96(3):527-33.

25. Huang J, Wang X, Zhang Y. Specific types of alcoholic beverage consumption and risk of type 2 diabetes: a systematic review and meta-analysis. Journal of Diabetes Investigation 2017: 
8(1), 56-68.

26. Schrieks I C, Heil A J, Hendriks H J, Mukamal K J, Beulens $\mathrm{J} \mathrm{J}$. The effect of alcohol consumption on insulin sensitivity and glycemic status: a systematic review and meta-analysis of intervention studies. Diabetes Care 2015:38(4), 723-732.

27. Clair C, Chiolero A, Faeh D. Dose-dependent positive association between cigarette smoking, abdominal obesity and body fat: cross-sectional data from a population-based survey. BMC Public Health 2011.

28. Pan A, Wang Y, Talaei M, Hu FB, Wu T. Relation of active, passive, and quitting smoking with incident diabetes: a meta-analysis and systematic review. Circulation 2015 Nov 10;132(19):1795-804.

29. Kim S K, Bae J C, Baek J, Jee J H, Hur K Y, Lee M, Kim, J $\mathrm{H}$. Decline in lung function rather than baseline lung function is associated with the development of metabolic syndrome: a six-year longitudinal study. Plos ONE 2017: 12(3), 1-9.

30. Dubbe JJ, Allison KF. Exercise dose and insulin sensitivity: relevance for diabetes prevention. Science Translational Medicine 2017 Apr 12;9(385).

31. Grøntved A, Pan A, Mekary R A, Stampfer M, Willett W C, Manson J E, Hu F B. Muscle-strengthening and conditioning activities and risk of type 2 diabetes: a prospective study in two cohorts of US women. Plos Medicine 2014:11(1), e1001587.

32. Hjerkind K V, Stenehjem J S, Nilsen T L. Adiposity, physical activity and risk of diabetes mellitus: prospective data from the population-based HUNT study, Norway. BMJ Open 2017: 7(1): e013142.

33. Crump C, Sundquist J, Winkleby M A, Sundquist K. Stress resilience and subsequent risk of type 2 diabetes in 1.5 million young men. Diabetologia 2016:59(4), 728-733.

34. Liu H, Song H, Tian R, Chen L, Zhang W, Qiang Y. Zhonghua Lao Dong Wei Sheng Zhi Ye Bing Za Zhi = Zhonghua Laodong Weisheng Zhiyebing Zazhi $=$ Chinese Journal of Industrial Hygiene and Occupational Diseases 2015; 33(2), 88-92.

\section{RELATIONSHIP OF LIFE-STYLE FACTORS WITH GLUCOSE LEVEL IN CAPILLARY BLOOD J. Kirvaitienė, R. Volskienė, L. Ambrožienè,}

\section{A. Vaičiulevičienè}

Key words: Diabetes mellitus, lifestyle, capillary blood.
Summary

According to the International Diabetes Federation, in the world diabetes sufferers are estimated to be 415 million people and $90 \%$ of them have type II Diabetes Mellitus. According to the data of Statistics Department of Lithuania, in 2016 out of 104,478 cases of Diabetes Mellitus registered in Lithuania, 99,197 people suffered from type II diabetes, which is mostly associated with the lifestyle habits. The level of glucose in capillary blood is the main diagnostic parameter that allows diabetes or pre-diabetic stage of disease to be detected. Scientific research has proven that type II diabetes can be prevented by keeping to work and resting regimen, not ignoring principles of healthy nutrition and giving time to physical activity.

The aim of the research was to determine the relationship between the lifestyle habits of Kauno Kolegija community members and the level of glucose in their capillary blood. Data for the survey was being collected in 2016 at the time of 3 events in Kauno Kolegija: the event dedicated to the "International Day of Health" on April 7, the celebration "Healthy, Active and Lively" on October 2, and the event to commemorate the "International Day of Diabetes"on November14.

During the events glucose concentration in capillary blood was measured, and participants responded to the questionnaire, describing their lifestyle. 117 members of Kauno Kolegija community volunteered to take part in the investigation.

The results of the study indicated that an increase in the level of glucose in the capillary blood of Kauno Kolegija community members at the time of momentary investigation had relation to the age, body mass index and physical activity $(\mathrm{p}<0.05)$. Respondents, who were diagnosed with the elevated levels of glucose in capillary blood, rated worse their health and nutrition, their activity was accompanied by nervous tension and they smoked more often.

Correspondence to: rasa.volskiene@go.kauko.lt

Gauta 2017-10-12 